\title{
Assessment of transplacental transmission of Neospora caninum in dairy cattle in the Agreste region of Pernambuco
}

Avaliação da transmissão transplacentária do Neospora caninum em bovinos de leite na região Agreste de Pernambuco

\begin{abstract}
Inalda Angélica de Souza Ramos ${ }^{1}$; Rafael José da Silva ${ }^{1}$; Thiago Arcoverde Maciel'; José Augusto Bastos Afonso da Silva ${ }^{2}$; Otavio Luiz Fidelis Junior ${ }^{3}$; Pierre Castro Soares ${ }^{4}$;

Rosangela Zacarias Machado5; Marcos Rogério André; Carla Lopes de Mendonçą ${ }^{2 *}$
\end{abstract}

\author{
${ }^{1}$ Programa de Pós-graduação em Sanidade e Reprodução de Ruminantes, Universidade Federal Rural de Pernambuco - UFRPE, \\ Garanhuns, PE, Brasil \\ ${ }^{2}$ Clínica de Bovinos, Universidade Federal Rural de Pernambuco - UFRPE, Garanhuns, PE, Brasil \\ ${ }^{3}$ Pós-graduaçáo em Medicina Veterinária, Universidade Estadual Paulista “Júlio de Mesquita Filho” - UNESP, Jaboticabal, SP, Brasil \\ ${ }^{4}$ Departamento de Medicina Veterinária, Universidade Federal Rural de Pernambuco - UFRPE, Recife, PE, Brasil \\ ${ }^{5}$ Departamento de Patologia Animal, Universidade Estadual Paulista "Júlio de Mesquita Filho" - UNESP, Jaboticabal, SP, Brasil
}

Received April 20, 2016

Accepted June 13, 2016

\begin{abstract}
The transplacental transmission is the primary route of Neospora caninum infection in bovine herds around the world. This study aimed to determine the frequency of transplacental transmission of the parasite in dairy cattle of Agreste region of Pernambuco through serological tests (IFAT and ELISA). Three hundred sixteen serum samples from cows and heifers and their offspring were analyzed. The transplacental transmission rate was $72.22 \%$ (13/18) for cows and $69.23 \%$ (9/13) for heifers by IFAT. ELISA test showed transplacental transmission rate of 43.58\% (17/39) for cows and 50\% (9/18) for heifers. The transplacental transmission rates were similar, in both groups in test, but a higher seropositivity was found in cows by IFAT. Data were statistically analyzed using the chi-square and Fisher's exact test. A significant relationship of dependence between seropositivity of mothers and their offspring was found. The more frequent IFAT antibody titers and ELISA levels for $N$. caninum were, respectively, 200 and between four (cows) and five (heifers and offspring). In the Spearman correlation, no association was found between the magnitude of antibody titers for $N$. caninum between mothers and their offspring. The kappa test showed an index of 0.35 , indicating a mild correlation between the serological tests used. The study suggests that cows and heifers are the main transmitters of $N$. caninum in the studied region and that vertical transmission is the major form of transmission in dairy herds of the Agreste region of Pernambuco.
\end{abstract}

Keywords: Neosporosis, dairy cows, IFAT, ELISA, Northeastern Brazil.

\section{Resumo}

A transmissão transplacentária é a principal via de infecção do Neospora caninum nos rebanhos bovinos em todo o mundo. O presente estudo teve como objetivo determinar a frequência da transmissão transplacentária do parasita em bovinos leiteiros do Agreste Pernambucano, por meio de testes sorológicos (RIFI e ELISA). Foram analisadas 316 amostras de soro de fêmeas bovinas (vacas e novilhas) e de suas crias. A taxa de transmissão transplacentária pela RIFI foi de $72,22 \%$ $(13 / 18)$ para vacas e 69,23\% (9/13) para as novilhas. O ELISA teste mostrou taxa de transmissáo transplacentária de $43,58 \%$ (17/39) para as vacas e 50\% (9/18) para as novilhas. As taxas de transmissão transplacentária foram similares para os dois testes em geral, porém uma maior soropositividade foi encontrada nas vacas pela RIFI. Os dados foram estatisticamente analisados pelo teste de qui-quadrado e teste exato de Fischer. Foi encontrada uma relação significativa de dependência entre a soropositividade das mães e de suas crias. Os títulos de anticorpos anti- N. caninum foi de 200 na

*Corresponding author: Carla Lopes de Mendonça. Universidade Federal

Rural de Pernambuco - UFRPE, Avenida Bom Pastor, s/n, Boa Vista, CP 152,

CEP 55292-270, Garanhuns, PE, Brasil. e-mail: carlalopes.mendonça@gmail.com 
RIFI e posicionados entre o nível quatro (vacas) e cinco (novilhas e bezerros) pelo ELISA. Pela correlação de Spearman, não foi observada associação entre a magnitude de títulos de anticorpos anti- $N$. caninum de fêmeas com o de suas crias. O teste de concordância kappa revelou um índice de 0,35 , indicando uma concordância leve entre os testes sorológicos utilizados. O estudo sugere que vacas e novilhas são as principais transmissoras do N. caninum na região estudada, sendo a transmissáo vertical, a principal forma de transmissão do agente em rebanhos leiteiros do Agreste de Pernambuco.

Palavras-chave: Neosporose, vacas de leite, RIFI, ELISA, Nordeste do Brasil.

Neosporosis is a disease that shows a global importance, with prevalence ranging from $0.07 \%$ to $97.2 \%$ (DUBEY \& SCHARES, 2011). Transplacental transmission is the main form of dissemination of neosporosis through cattle herds, and is considered to be one of the main causes of abortion in livestock. The parasite may cause chronic infection, remaining within the herd across the generations and giving rise to reproduction losses (DUBEY et al., 2007). When infection occurs during the final third of gestation, fetal deaths and abortions hardly ever occur and offspring appear to be healthy when in fact they are persistently infected (DUBEY \& SCHARES, 2011). The horizontal infection occurs due to the presence of the main definitive hosts, represented by dogs, coyotes (Canis latrans) and Australian dingos (Canis lupus dingo) (McALLISTER et al., 1998; GONDIM et al., 2004; KING et al., 2010), which eliminate Neospora caninum oocysts in their faeces and can contaminate food items and water, keeping the infection between generations through of transplacental transmission (DUBEY et al., 2007).

Transplacental transmission of $N$. caninum can be estimated from the number of seropositive offspring born from seropositive mothers, soon after their birth and before ingestion of colostrum (PARÉ et al., 1996).Among the techniques used to show whether neosporosis is involved as a disease with in the reproductive sphere, the Indirect Fluorescente Antibody Test (IFAT) and Enzyme-Linked Immunosorbent Assay (ELISA) are the major serological tests used in the routine (PARÉ et al., 1996; JENKINS et al., 2002).

Serological studies characterizing the frequency of transplacental transmission among offspring, before ingestion of colostrum, have been reported in Brazil (VIANNA et al., 2008; MARQUES et al., 2011; HEIN et al., 2012; SANTOS et al., 2012; MACEDO et al., 2013), but none have been conducted in the state of Pernambuco up to now. In this state, the dairy cattle has been established historically in the Agreste region, counting with approximately 169.581 million dairy cattle (IBGE, 2010). The present study aimed to evaluate the frequency of transplacental transmission of $N$. caninum between dairy cattle (cows and heifers) and their respective offspring before ingestion of colostrum, in the Agreste region of Pernambuco, by serological techniques.

One hundred fifty eight female cattle (113 cows and 45 heifers), without previous reports of reproductive problems, that were assisted during delivery at the Cattle Clinic, Garanhuns campus, Federal Rural University of Pernambuco (UFRPE), and their respective offspring ( $\mathrm{n}=158$ ), were evaluated, totalizing 316 animals. Samples were collected at delivery, during the period of 2003-2013. Animal were originated from 25 municipalities of the Agreste region of Pernambuco: Pesqueira (6/316), São João (22/316), Canhotinho (8/316), Garanhuns (68/316), Venturosa (14/316), Correntes (18/316), Paranatama (8/316), Bom Conselho (10/316), Lagoa do
Ouro (16/316), Jucatí (14/316), Caetés (24/316), Pedra (32/316), Palmerina (6/316), Alagoinha (2/316), Saloá (2/316), Angelim (8/316), Teresinha (2/316), (2/316), Brejão (6/316), Lajedo (6/316), São Bento do Una (38/316), Iatí (2/316), Quipapá (2/316) and Ibirajuba (2/316). The animals were Holstein, Girolanda and also mixed breed. Positivity in each municipality was calculated by the number of positive animals divided by the total number of animals sampled.

Blood collection was performed during delivery, for cows and heifers, and soon after birth, before ingestion of colostrum, for offspring, totaling 316 samples (158 adults and 158 offspring). Blood samples from females and their respective offspring were collected by venipuncture of the external jugular, using the Vacutainer ${ }^{\oplus}$ system (B.D. Indústria Cirúrgica, Juiz de Fora, MG), in silicon-treated tubes without anticoagulant. Samples were then centrifuged at $3.500 \mathrm{rpm}$ for 10 minutes for serum obtainment, which were liquated in polypropylene microtubes and then kept frozen in ultrafreezer $\left(-80^{\circ} \mathrm{C}\right)$, until the time of use.

For IFAT, tachyzoites of the isolate Nc-1 of $N$. caninum cultured in Vero cells were used as antigens, which were deposited on previously marked wells (MINEO et al., 2009). Ten serum samples were tested on each slide and were compared with negative and positive controls. The positive e negative controls serum samples were obtained from the serum bank of the Immunoparasitology Laboratory, UNESP Jaboticabal. Test serum samples and positive e negative controls were diluted at 1:200. After dilution (1:200) in phosphate-buffered saline solution (PBS) ( $\mathrm{pH} 7.2$; $1.3 \mathrm{M} \mathrm{NaCl}, 27 \mathrm{M} \mathrm{KCl}, 56 \mathrm{mM} \mathrm{Na}_{2} \mathrm{HPO}_{4}, 10 \mathrm{mM} \mathrm{KH}_{2} \mathrm{PO}_{4}$ and $9.2 \mathrm{mM} \mathrm{NaH}_{2} \mathrm{PO}_{4}$ ), $10 \mu \mathrm{L}$ of diluted serum samples were deposited in each slide well. The slides were then incubated at $37^{\circ} \mathrm{C}$ for 30 minutes in humid chamber. After incubation, slides were washed three times with PBS for five minutes, consecutively, and then dried at room temperature. Following this, $10 \mu \mathrm{L}$ of conjugate (anti-IgG-bovine-SIGMA ${ }^{\oplus}$, St. Louis, Missouri, United States) diluted in PBS at 1:300 was added to each slide well. Then, slides were incubated in humid chamber again, at $37{ }^{\circ} \mathrm{C}$ for 30 minutes, with subsequent washing, as described previously.

After the slides had been dried at room temperature, buffered glycerin was added (glycerin and $0.5 \mathrm{M}$ carbonate-bicarbonate buffer at $\mathrm{pH}$ 9.6), and then covered with a cover slips, for observation at a magnification of $400 \mathrm{X}$, under a microscope equipped with fluorescent light (Olympus BX-FLA). Test positivity was determined through observation of total peripheral fluorescence of the tachyzoites, using a cutoff point of 1:200. Positive samples were subjected to sequential dilutions at base 2, to determine the antibody titers (DUBEY et al., 1988; MINEO et al., 2009).

The indirect ELISA was performed as previously described by Machado et al. (1997), with some modifications. There was 
no need for block standardization, since there was a standardized protocol for the antigen under study. To sensitize the ELISA plate (NUNC MaxiSport ${ }^{\oplus}$ ), $10 \mu \mathrm{g} / \mathrm{mL}$ of crude soluble antigen of $N$. caninum was diluted in carbonate-bicarbonate buffer ( $\mathrm{pH}$ 9.6; $0.5 \mathrm{M})$. One hundred microliters of the diluted antigen was added to each plate well, and then were incubated for $12-14 \mathrm{~h}$ in a humid chamber at $4{ }^{\circ} \mathrm{C}$. After this period, the excess antigen was discarded and the plate was blocked using $6 \%$ powdered skimmed milk (blocker), in carbonate-bicarbonate buffer. For every plate well, $200 \mu \mathrm{L}$ of the blocker was added, followed by incubation in the humid chamber at $37^{\circ} \mathrm{C}$ for one hour. After removal of the blocking solution, the plate was washed three times with PBS Tween-20. One hundred microliters of the serum diluted at 1:400 in PBS Tween-20 were added to each well and, once again, the plate was incubated in the humid chamber at $37^{\circ} \mathrm{C}$ for one hour, with subsequent washing, as previously described.

One hundred microliters of anti-IgG-bovine conjugate (SIGMA ${ }^{\oplus}$, St. Louis, Missouri, United States), bound to alkaline phosphatase, diluted at 1:30.000 in PBS Tween-20, was added to each plate well. Plates were then incubated and washed in the same manner as described previously. The enzyme substrate (p-nitrophenyl), at the concentration of $1 \mathrm{mg} / \mathrm{mL}$, was diluted in diethanolamine buffer ( $\mathrm{pH}$ 9.8), and then $100 \mu \mathrm{L}$ of the dilution was added per well. Plates were incubated at room temperature protected from the light for 30 minutes. The reaction was read using a microplate reader for ELISA (Microplate Reader MRX TC Plus, Dynex Technology, USA), at the wavelength of $405 \mathrm{~nm}$. The well cavity of the microplate that contained all the reaction elements except for bovine serum was used as reaction "blank". After the reading, the absorbance values were calculated in accordance with Machado et al. (1997), with subsequent determination of ELISA levels.

In order to determinate the frequencies of anti- $N$. caninum antibodies in cows, heifers and their respective offspring, and also in the seroepidemiological survey of infection by this parasite in the municipalities of the Agreste region of Pernambuco, descriptive statistics was performed. The data were expressed as measurements of relative frequency. To evaluate the general transplacental transmission rates among females according to the categories (cow and heifer), as measured by IFAT and ELISA, McNemar' schi-square test or Fisher's exact test (when the assumptions used to carry out the chi-square test were not achieved) was performed, in association with descriptive statistics. Spearman's correlation (r) was used to ascertain the degree of magnitude between the titers observed in the cows and heifers and their respective offspring
(SAMPAIO, 2007). A significance level $(\alpha)$ of $5 \%$ was used for these tests. The coefficient of concordance between IFAT and ELISA was estimated using the kappa test (LANDIS \& $\mathrm{KOCH}$, 1977). The results were analyzed using the Statistical Analysis System Software, version 9.2.

Of the total number of evaluated females (cows and heifers), $19.62 \%$ (31/158) and 36.07\% (57/158) were seropositive for $N$. caninum, according to IFAT and ELISA, respectively. Among the 25 evaluated municipalities, seropositivity animals were found in Palmerina (100\%), Lagoa do Ouro (100\%), Canhotinho (38\%), Caetés (33\%), Lajedo (33\%), Paranatama (25\%), São João (23\%), Pedra (19\%), Brejão (17\%), São Bento (16\%), Garanhuns (16\%), Venturosa (14\%), Jucati (14\%) and Correntes (11\%) (Figure 1).

By assessing the seropositivity dependent relationship between cows and heifers and their calves using IFAT, it was found that there was dependence between animal categories, shown by Fisher's exact test for cows and their offspring $(p<0.0001)$ and heifers and their descendants $(\mathrm{p}=0.0106)$. The ELISA test also showed a significant association of the serological results between cows and their offspring $(\mathrm{p}=0.0045)$, but not among heifers and their descendants by Fisher's exact test $(\mathrm{p}=0.1257)$ (Table 1$)$.

The transplacental transmission rate varies according to the category studied. By IFAT, cows and heifers showed rates of $72.22 \%$ $(13 / 18)$ and $69.23 \%(9 / 13)$, respectively. On the other hand, the transplacental transmission rates were $43.58 \%$ (17/39) for cows and 50\% (9/18) for heifers by ELISA (Table 1).

There was no correlation between the magnitudes of titers obtained by IFAT for $N$. caninum, for cows and their offspring $(\mathrm{r}=0.1817 ; \mathrm{p}=0.4305)$ and for heifers and their calves $(\mathrm{r}=-0.138$; $\mathrm{p}=0.6102)$ according to the Spearman test. Most seropositive animals (23/316; 7.28\%) showed titers of 200 by IFAT (Figure 2). Among the seropositive animals by ELISA, cows were predominant at level four and heifers and offspring at level five (Figure 3). In order to check the degree of agreement between the serological tests employed, considering IFAT as the gold standard, kappa test was performed, showing an index of 0.35 (low correlation).

The found seropositivity rate ranging from $22.78 \%$ and $39.24 \%$ by IFAT and ELISA, respectively, was within the values obtained in other parts of the world that ranged from $0.07 \%$ to $97.2 \%$ (DUBEY \& SCHARES, 2011). The rate was also consistent with those obtained from animals tested by researchers in others Brazilian states, such as Goiás (MELO et al., 2001; OLIVEIRA et al., 2010), Paraná (OGAWA et al., 2005; LOCATELLI-DITTRICH et al., 2001; MARQUES et al., 2011), Minas Gerais (CORBELLINI et al., 2002; SANTOS et al., 2012), Rio Grande do Sul (RAGOZO et al., 2003;

Table 1. Serological results for Neospora caninum by IFAT and ELISA, according to the animal category (cows, heifers and their offspring), in Garanhuns, 2003-2013.

\begin{tabular}{|c|c|c|c|c|c|c|c|c|}
\hline \multirow{3}{*}{ Offspring } & \multicolumn{4}{|c|}{ IFAT } & \multicolumn{4}{|c|}{ ELISA } \\
\hline & \multicolumn{2}{|c|}{ Cow } & \multicolumn{2}{|c|}{ Heifer } & \multicolumn{2}{|c|}{ Cow } & \multicolumn{2}{|c|}{ Heifer } \\
\hline & Positive & Negative & Positive & Negative & Positive & Negative & Positive & Negative \\
\hline Positive & 10 & 3 & 6 & 3 & 11 & 6 & 6 & 3 \\
\hline Negative & 8 & 92 & 7 & 29 & 28 & 68 & 12 & 24 \\
\hline TOTAL & 18 & 95 & 13 & 32 & 39 & 74 & 18 & 27 \\
\hline p-value & \multicolumn{2}{|c|}{$<0.0001$} & \multicolumn{2}{|c|}{0.0106} & \multicolumn{2}{|c|}{0.0045} & \multicolumn{2}{|c|}{0.1257} \\
\hline
\end{tabular}




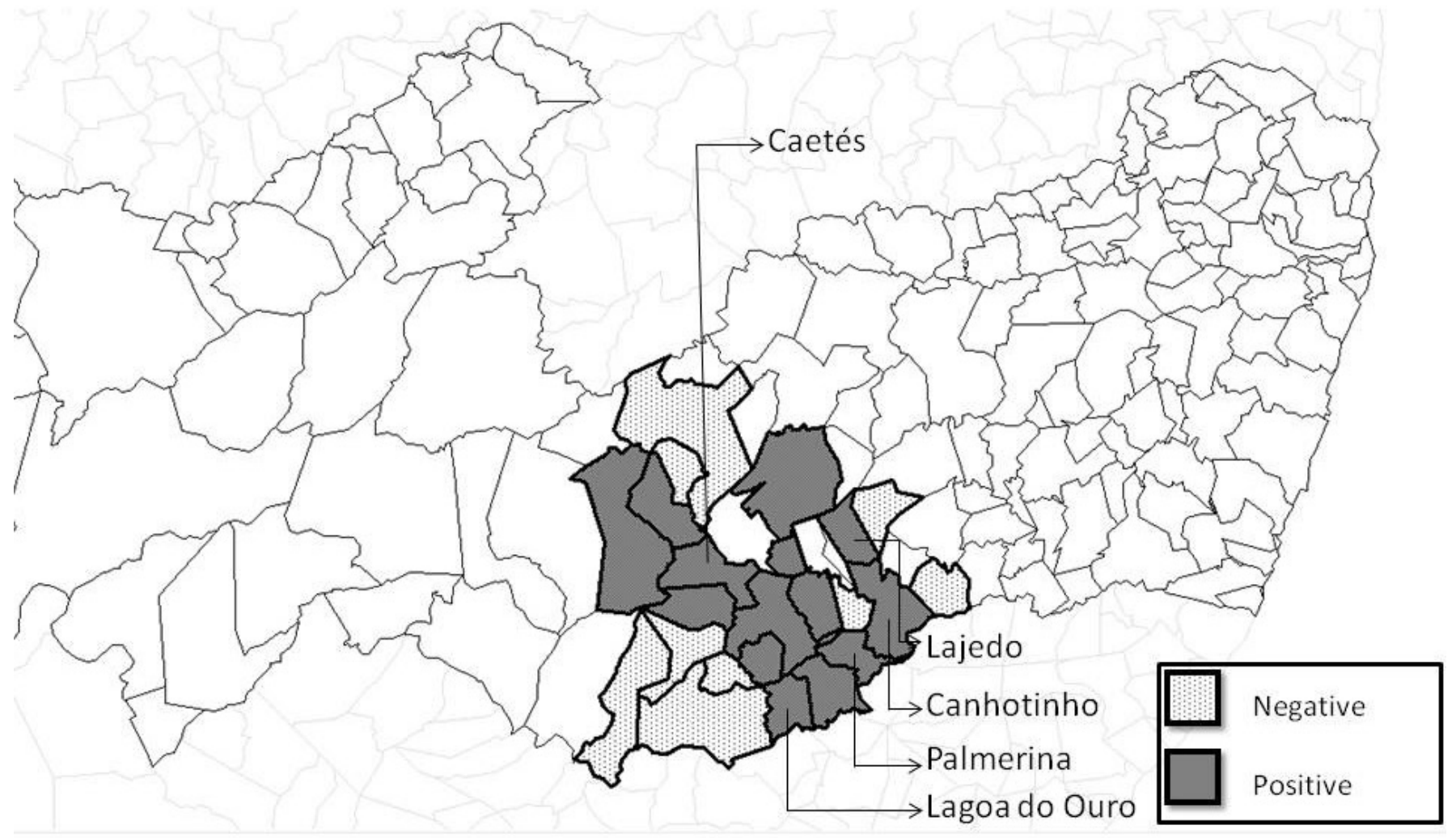

Figure 1. Map of distribution of seropositive $(\mathrm{n}=53)$ and seronegative $(\mathrm{n}=263)$ animals (cows, heifers and their offspring) for Neospora caninum by IFAT assisted in the Garanhuns cattle Clinic 2003-2013, in the Agreste region of Pernambuco, Brazil. Municipalities with higher seropositivity (Caetes, Lajedo, Canhotinho, Palmerina and Lagoa do Ouro).

\section{Indirect Fuorescent Antibody Test (IFAT)}

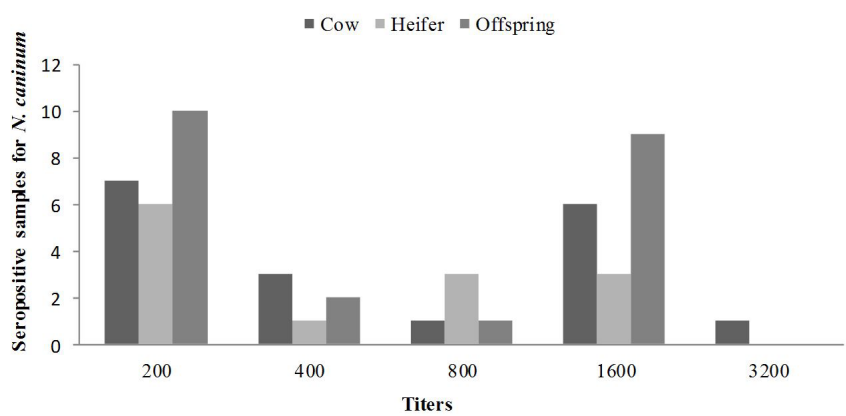

Figure 2. Distribution of animals according to IFAT titers of antibodies to N.caninum and animal categories (cow, heifer and offspring), in Garanhuns, 2003-2013.

HEIN et al., 2012), Santa Catarina (MACEDO et al., 2013), São Paulo (SARTOR et al., 2003), Tocantins (MARTINS et al., 2011), Mato Grosso do Sul, Rio de Janeiro (MUNHOZ et al., 2006), Rondônia (AGUIAR et al., 2006; MARQUES et al., 2011; ANDREOTTI et al., 2004), Alagoas (SOUSA et al., 2012) and Bahia (GONDIM et al., 2004), where the values ranged from $6 \%$ to $58 \%$. In the state of Pernambuco, Silva et al. (2008)

\section{ELISA levels}

- Cows $=$ Heifers $=$ Offspring

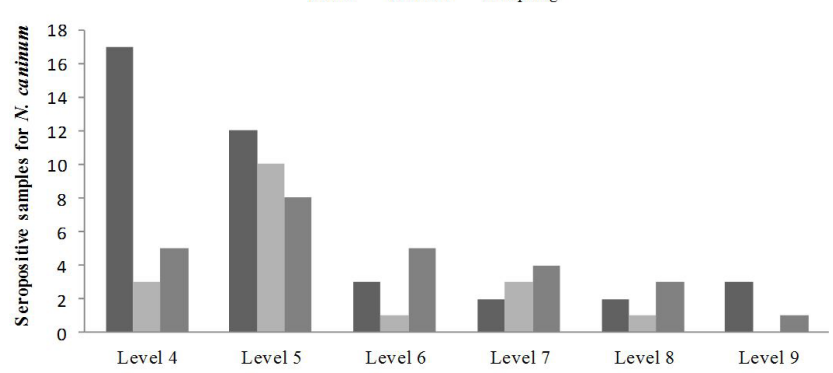

Figure 3. Distribution of animals according to ELISA levels of antibodies to $N$. caninum and animal categories (cow, heifer and offspring), in Garanhuns, 2003-2013. ELISA level $\geq 4$ = Positive; according to the formula previously described by Machado et al. (1997).

found a seropositive frequency of $31.7 \%$ in herds belonging to large milk producers located in Gravesend, by IFAT. Moreover, Amaral et al. (2012), evaluating beef cattle from slaughterhouses of the micro-region of Brejo/PE, found a seropositivity rate of $17.3 \%$, which was also consistent with our results.

In this study, some municipalities of the Agreste region of Pernambuco (Lagoa do Ouro, Canhotinho, Caetés, Lajedo and 
Palmerina), which concentrated a large number of milk producers (SEBRAE, 2013; DUBEY \& SCHARES, 2011), showed higher rates of seropositivity than those found among animals in other municipalities.

By serological tests (IFAT or ELISA) revealed that there was significant association ( $\mathrm{p} \leq 0.05$ ) of seropositivity between mother and offspring, except by ELISA for heifers and offspring. This supports of hypothesis that transplacental route is a major source of transmission and maintenance of neosporosis in dairy cattle to successive generations (ANDERSON et al., 1997). The transplacental transmission rate was similar between the two groups studied, using both serologic techniques, but higher seropositivity was found by IFAT for cows. Higher vertical transmission rate in cows may be related to chronic infections in dairy herds, where animals remain much active time in the production system, spreading the agent over the generations (INNES et al., 2005; DUBEY \& SCHARES, 2011). Innes et al. (2000) reported that older animals showed better immune adaptation to the parasite than younger animals, but may have the reactivation of infection in immunosuppressive situations.

It is also important to highlight that the occurrence of birth of seropositive calves from seronegative mothers (cows [3/10] and heifers [3/6]), totalizing six seropositive offspring from sixteen negative females by IFAT, could be due to the infection of mother have happened some time ago and the antibody level is maintained at a level below the detection threshold of serological tests (CONRAD et al., 1993; FRÖSSLING et al., 2005; LÓPEZ-GATIUS et al., 2005; SAGER et al., 2001). This condition was also observed by Frössling et al. (2005) and López-Gatius et al. (2004) in cattle from Sweden.

The presence of antibody titers in calves before colostrum feeding proves transplacental transmission, since maternal antibodies do not cross the placenta in cattle, and can assume that the presence of antibodies in calves immediately after birth, before the intake of colostrum, are generated in uterus resulting $N$. caninum infection. The frequency of transplacental transmission can be estimated by the number of seropositive calves soon after birth before colostrum intake, born from seropositive mothers (BARTELS et al., 2007).

In this study, there was no correlation between the magnitude of anti- $N$. caninum antibodies titers between mothers and their offspring. On the other hand, Dubey et al. (2007) reported that the magnitude of antibody titers of infected calves showed concordance with the magnitude of those from their mothers. Hietala \& Thurmond (1999) emphasizes the need of special attention of the researchers when interpreting the serological results for $N$. caninum in cattle aged between 13 and 24 months of age, because of the possibility of false negative results, due to the decline of antibodies in the old congenitally infected animals. Serological studies have suggested that titles $\geq 200$ (IFAT) are specific to infection by $N$. caninum (DUBEY et al., 1996), while the highest titers have been associated with occurrence of abortions (TREES et al., 1993). According to Cox et al. (1998), high titers of anti- $N$. caninum antibodies quickly decline after the abortion, but low positive titers may persist for a long time.

According to the kappa index, IFAT and ELISA crude antigen presented concordance mild (0.35). IFAT was the first serological test used to demonstrate the presence of antibodies for N.caninum
(DUBEY \& SCHARES, 2011). Cross-reactions with other coccidia are almost non-existent, so it is used as a benchmark for comparison with other serological tests. However, comparing indirect ELISA based on NcSRS2 recombinant antigen for detecting anti- $N$ caninum antibodies in sheep, Andreotti et al. (2009) found that these two tests showed similar concordance with an excellent kappa $(0,98)$. Indirect ELISA based on the recombinant protein NcSRS2 was shown to be a highly sensitive and specific tool for serological diagnosis of $N$. caninum, since it reduces the occurrence of nonspecific cross reactions (ANDREOTTI et al., 2009).

\section{Conclusion}

The high rates of transplacental transmission observed in this study, either by IFAT or ELISA, may indicate that this type of transmission plays an important role in the maintenance and transmission of $N$. caninum in dairy cattle herds in the Agreste region of Pernambuco.

\section{Acknowledgements}

We thank the Foundation for Science and Technology Support (Fundação de Amparo à Ciência e Tecnologia; FACEP/IBPG no 1297-5. 05/12), for providing the master's scholarship and PROCAD/CAPES (PROCAD-NF no 21/2009, convention no. $363 / 2010$ ), for the exchange between postgraduate programs (UFRPE, Garanhuns campus, and UNESP Jaboticabal).

\section{References}

Aguiar DM, Cavalcante GT, Rodrigues AAR, Labruna MB, Camargo LMA, Camargo EP, et al. Prevalence of anti-Neospora caninum antibodies in cattle and dogs from Western Amazon, Brazil, in association with some possible risk factors. Vet Parasitol 2006; 142(1-2): 71-77. http://dx.doi. org/10.1016/j.vetpar.2006.06.014.

Amaral RLG, Silva LGB, Pinheiro JW Jr, Souza OL No, Leal CAS, Porto WJN, et al. Neospora caninum em bovinos em matadouros de Pernambuco e Alagoas. Pesqui Vet Bras 2012; 32(10): 963-966. http:// dx.doi.org/10.1590/S0100-736X2012001000002.

Anderson ML, Reynolds JP, Rowe JD, Sverlow KW, Packham AE, Barr BC, et al. Evidence of vertical transmission of Neospora sp. infection in dairy cattle. J Am Vet Med Assoc 1997; 210(8): 1169-1172.

Andreotti R, Matos MFC, Gonçalves KN, Oshiro LM, Lima MSC Jr, Paiva F, et al. Comparison of indirect ELISA based on recombinant protein NcSRS2 and IFAT for detection of Neospora caninum antibodies in sheep. Rev Bras Parasitol Vet 2009; 18(2): 19-22. http://dx.doi.org/10.4322/ rbpv.01802004.

Andreotti R, Pinckney RD, Pires PP, Silva EAE. Evidence of Neospora caninum in beef cattle and dogs in the state of Mato Grosso do Sul, center-western region, Brazil. Rev Bras Parasitol Vet 2004; 13(3): 129-131.

Bartels CJ, Huinink I, Beiboer ML, van Schaik G, Wouda W, Dijkstra T, et al. Quantification of vertical and horizontal transmission of Neospora caninum infection in Dutch dairy herds. Vet Parasitol 2007; 148(2): 83 92. http://dx.doi.org/10.1016/j.vetpar.2007.06.004. 
Conrad PA, Barr BC, Sverlow KW, Anderson M, Daft B, Kinde H, et al. In vitro isolation and characterization of a Neospora sp. from aborted bovine foetuses. Parasitology 1993; 106(3): 239-249. http://dx.doi. org/10.1017/S0031182000075065.

Corbellini LG, Driemeier D, Cruz CEF, Gondim LFP, Wald V. Neosporosis as a cause of abortion in dairy cattle in Rio Grande do Sul, southern Brazil. Vet Parasitol 2002; 103(3): 195-202. http://dx.doi.org/10.1016/ S0304-4017(01)00600-8.

Cox BT, Reichel MP, Griffiths LM. Serology of a Neospora abortion outbreak on a dairy farm in New Zealand: a case study. NZ Vet J 1998; 46(1): 28-31. http://dx.doi.org/10.1080/00480169.1998.36046.

Dubey JP, Carpenter JL, Speer CA, Topper MJ, Uggla A. Newly recognized fatal protozoan disease of dogs. J Am Vet Assoc 1988; 192(9): 1269-1285.

Dubey JP, Lindsay DS, Adams DS, Gay JM, Baszler TV, Blagburn BL, et al. Serologic responses of cattle and other animals infected with Neospora caninum. Am J Vet Res 1996; 57(3): 329-336.

Dubey JP, Schares G, Ortega-Mora LM. Epidemiology and control of neosporosis and Neospora caninum. Clin Microbiol Rev 2007; 20(2): 323-367. http://dx.doi.org/10.1128/CMR.00031-06.

Dubey JP, Schares G. Neosporosis in animals: the last five years. Vet Parasitol 2011; 180(1-2): 90-108. http://dx.doi.org/10.1016/j.vetpar.2011.05.031.

Frössling J, Uggla A, Björkman C. Prevalence and transmission of Neospora caninum within infected Swedish dairy herds. Vet Parasitol 2005; 128(34): 209-218. http://dx.doi.org/10.1016/j.vetpar.2004.12.006.

Gondim LFP, McAllister MM, Pitt WC, Zemlicka D. Coyotes (Canis latrans) are definitive hosts of Neospora caninum. Int J Parasitol 2004; 34(2): 159-161. http://dx.doi.org/10.1016/j.ijpara.2004.01.001.

Hein HE, Machado G, Miranda ICS, Costa EF, Pellegrini DCP, Driemeier D, et al. Neosporose bovina: avaliação da transmissão vertical e fração atribuível de aborto em uma população de bovinos no Estado do Rio Grande do Sul. Pesq Vet Bras 2012; 32(5): 396-400. http://dx.doi. org/10.1590/S0100-736X2012000500006.

Hietala SK, Thurmond MC. Postnatal Neospora caninum transmission and transient serologic responses in two dairies. Int J Parasitol 1999; 29(10): 1669-1676. http://dx.doi.org/10.1016/S0020-7519(99)00102-2.

Innes EA, Buxton D, Maley S, Wright S, Marks J, Esteban I, et al. Neosporosis: aspects of epidemiology and host immune response. Ann N Y Acad Sci 2000; 916(1): 93-101. http://dx.doi.org/10.1111/j.1749-6632.2000. tb05278.x.

Innes EA, Wright S, Bartley P, Maley S, Macaldowie C, Esteban-Redondo I, et al. The host-parasite relationship in bovine neosporosis. Vet Immunol Immunopathol 2005; 108(1-2): 29-36. http://dx.doi.org/10.1016/j. vetimm.2005.07.004.

Instituto Brasileiro de Geografia e Estatística - IBGE. Produção da Pecuária Municipal. Rio de Janeiro: IBGE; 2010. p. 55-61. vol. 38. Boletim Técnico.

Jenkins M, Baszler T, Bjorkman C, Schares G, Williams D. Diagnosis and seroepidemiology of Neospora caninum-associated bovine abortion. Int J Parasitol 2002; 32(5): 631-636. http://dx.doi.org/10.1016/S00207519(01)00363-0.

King JS, Slapeta J, Jenkins DJ, Al-Qassab SE, Ellis JT, Windsor PA. Australian dingoes are definitive hosts of Neospora caninum. Int J Parasitol 2010; 40(8): 945-950. http://dx.doi.org/10.1016/j.ijpara.2010.01.008.
Landis JR, Koch GG. The measurement of observer agreement for categorical data. Biometrics 1977; 33(1): 159-174. http://dx.doi. org/10.2307/2529310.

Locatelli-Dittrich R, Soccol VT, Richartz RR, Gasino-Joineau ME, Vinne R, Pinckney RD. Serological Diagnosis of Neosporosis in a Herd of Dairy Cattle in Southern Brazil. J Parasitol 2001; 87(6): 1493-1494. http:// dx.doi.org/10.1645/0022-3395(2001)087[1493:SDONIA]2.0.CO;2.

López-Gatius F, López-Béjar M, Murugavel K, Pabón M, Ferrer D, Almería S. Neospora-associated abortion episode over a 1-year period in a dairy herd in north-east Spain. J Vet Med B Infect Dis Vet Public Health 2004; 51(7): 348-352. http://dx.doi.org/10.1111/j.1439-0450.2004.00779.x.

López-Gatius F, Santolaria P, Yaniz JL, Garbayo JM, Almería S. The use of beef bull semen reduced the risk of abortion in Neospora-seropositive dairy cows. J Vet Med B Infect Dis Vet Public Health 2005; 52(2): 88-92. http://dx.doi.org/10.1111/j.1439-0450.2004.00818.x.

Macedo CAB, Macedo MFSB, Cardim ST, Paiva MCDC, Tadora A, Barros LD, et al. Neospora caninum: evaluation of vertical transmission in slaughtered dairy cows (Bos taurus). Rev Bras Parasitol Vet 2013; 22(1): 13-17. http://dx.doi.org/10.1590/S1984-29612013000100004.

Machado RZ, Montassier HJ, Pinto AA, Lemos EG, Machado MRF, Valadão IFF, et al. An enzyme-linked immunosorbent assay (ELISA) for the detection of antibodies against Babesia bovis in cattle. Vet Parasitol 1997; 71(1): 17-26. http://dx.doi.org/10.1016/S0304-4017(97)00003-4.

Marques FAC, Headley AS, Pereira VF, Taroda A, Barros LD, Cunha IAL, et al. Neospora caninum: evaluation of vertical transmission in slaughtered beef cows (Bos indicus). Parasitol Res 2011; 108(4): 10151019. http://dx.doi.org/10.1007/s00436-010-2146-x.

Martins NEX, Freschi CR, Baptista F, Machado RZ, Freitas FLC, Almeida KS. Ocorrência de anticorpos anti-Neospora caninum em vacas lactantes do Município de Araguaína, Estado do Tocantins, Brasil. Rev Patol Trop 2011; 40(3): 231-238.

McAllister MM, Dubey JP, Lindsay DS, Jolley WR, Wills RA, Mcguire AM. Dogs are definitive hosts of Neospora caninum. Int J Parasitol 1998; 28(9): 1473-1478. http://dx.doi.org/10.1016/S0020-7519(98)00138-6.

Melo CB, Leite RC, Souza GN, Leite RC. Frequency of Neospora caninum infection in two different milk production system and predicting factors to infection on cattle herds in the State of Minas Gerais, Brazil. Rev Bras Parasitol Vet 2001; 10(2): 67-74.

Mineo TWP, Carrasco AOT, Marciano JA, Werther K, Pinto AA, Machado RZ. Pigeons (Columba livia) are a suitable experimental model for Neospora caninum infection in birds. Vet Parasitol 2009; 159(2): 149-153. http:// dx.doi.org/10.1016/j.vetpar.2008.10.024.

Munhoz AD, Flausino W, Silva RT, Almeida CR, Lopes CW. Distribution of anti-Neospora caninum antibodies in dairy cows at Municipalities of Resende and Rio Claro in the State of Rio de Janeiro, Brazil. Rev Bras Parasitol Vet 2006; 15(3): 101-104.

Ogawa L, Freire RL, Vidotto O, Gondim LFP, Navarro IT. Occurrence of antibodies to Neospora caninum and Toxoplasma gondii in dairy cattle from the northern region of the Paraná State, Brazil. Arq Bras Med Vet Zootec 2005; 57(3): 312-316. http://dx.doi.org/10.1590/S010209352005000300006.

Oliveira VSF, Álvarez-Garcia G, Ortega-Mora LM, Borges LMF, Silva AC. Abortions in bovines and Neospora caninum transmission in an embryo transfer Center. Vet Parasitol 2010; 173(3-4): 206-210. http:// dx.doi.org/10.1016/j.vetpar.2010.06.028. 
Paré J, Thurmond MC, Hietala SK. Congenital Neospora caninum infection in dairy cattle and associated calfhood mortality. Can J Vet Res 1996; 60(2): 133-139.

Ragozo AMA, Paula VSO, Souza SLP, Bergamaschi DP, Gennari SM. Ocorrência de anticorpos anti-Neospora caninum em soros bovinos procedentes de seis estados brasileiros. Rev Bras Parasitol Vet 2003; 12(1): 33-37.

Sager H, Fischer I, Furrer K, Strasser M, Waldvogel A, Boerlin P, et al. A swiss case-control study to assess Neospora caninum: associated bovine abortions by PCR, histopathology and serology. Vet Parasitol 2001; 102(1-2): 1-15. http://dx.doi.org/10.1016/S0304-4017(01)00524-6.

Sampaio IVB. Testes estatísticos não paramétricos. In: Sampaio IVB. Estatística aplicada à experimentação animal. 3. ed. Belo Horizonte: Fundação de Ensino e Pesquisa em Medicina Veterinária e Zootecnia; 2007. p. 207-223.

Santos RRD, Rocha CMBM, Gonçalves TM, Guimarães AM. Quantification of vertical transmission of Neospora caninum in dairy cows in Minas Gerais, Brazil. Rev Bras Parasitol Vet 2012; 21(3): 294-297. http://dx.doi. org/10.1590/S1984-29612012000300021.

Sartor IF, Hasegawa MY, Canavessi AMO, Pinckney RD. Ocorrência de anticorpos de Neospora caninum em vacas leiteiras avaliados pelos métodos de ELISA e IFAT no município de Avaré, SP. Semina: Ciênc Agrár 2003; 24(1): 3-10.

Serviço de Apoio Brasileiro às Micro e Pequenas Empresas - SEBRAE. Cenários para o leite e derivados na Regiāo Nordeste em 2020. Recife: SEBRAE; 2013. $154 \mathrm{p}$.

Silva MIS, Almeida MAO, Mota RA, Pinheiro JWP Jr, Rabelo SSA. Fatores de riscos associados à infecção por Neospora caninum em Matrizes Bovinas Leiteiras em Pernambuco. Ciênc Anim Bras 2008; 9(2): 455-461.

Sousa ME, Porto WJN, Albuquerque PPF, Souza OLS No, Faria EB, Pinheiro JWP Jr, et al. Soroprevalence and risk factors associated with infection by Neospora caninum of dairy cattle in the state of Alagoas, Brazil. Pesq Vet Bras 2012; 32(10): 1009-1013. http://dx.doi.org/10.1590/ S0100-736X2012001000011.

Trees AJ, Guy F, Tennant BJ, Balfour AH, Dubey JP. Prevalence of antibodies to Neospora caninum in a population of urban dogs in England. Vet Rec 1993; 132(6): 125-126. http://dx.doi.org/10.1136/vr.132.6.125.

Vianna LC, Sartor IF, Pituco EM, Okuda LH, Camargo CN, Kronka $\mathrm{SN}$. Incidência e transmissáo transplacentária de Neospora caninum em fêmeas primíparas da raça Bos indicus abatidos em Presidente Prudente, São Paulo, Brasil. Semina: Ciênc Agrár 2008; 29(2): 387-392. 